\title{
COMPREHENDING PERSONAL EXPERIENCE: IMPLEMENTING BUZZ GROUP IN TEACHING READING
}

\author{
Dian Hapsari ${ }^{1}$, M. Sayid Wijaya ${ }^{2}$ \\ Universitas Islam Negeri (UIN) Raden Intan Lampung, Indonesia \\ Email: dhapsari3@gmail.com ${ }^{1}$, \\ Email: sayidwijaya@radenintan.ac.id ${ }^{2}$
}

\begin{abstract}
The students' reading comprehension of SMA Negeri 2 Tumijajar is still low especially in reading personal recount text. To solve the problem, the researcher applied Buzz Group. The objective of this research is to know whether there is a significant influence of using Buzz Group towards students' reading comprehension on personal recount text at the eleventh grade of SMA Negeri 2 Tumijajar in the academic 2018/2019. The research methodology was quasi experimental design. In this research, the population was the eleventh grade of SMA Negeri 2 Tumijajar. The sample of this research was two classes consisting of 33 students for experimental class and 33 students for control class. In the experimental class, the researcher used Buzz Group and in the control class the teacher used think pair share. The treatments were held in 3 meetings in which $2 \times 45$ minutes for each class. In collecting data, the researcher used instrument in the form of multiple choice questions which had been tried out prior to the treatments. The instrument was given in pre-test and post-test. The researcher analyzed the data by using SPSS to compute independent sample t-test. From the data analysis computed by SPSS, it was obtained that Sig. $=0.002$ and $\alpha=0.05$. It means Ha is accepted because Sig. $<\alpha$ $=0.002<0.05$. Therefore, there is a significant influence of using Buzz Group towards students' reading comprehension on personal recount text at the eleventh grade of SMA Negeri 2 Tumijajar in the academic year 2018/2019.
\end{abstract}

Keyword: Buzz Group, personal recount text, Reading comprehension.

\section{INTRODUCTION}

Reading is one of the language skills that must be mastered by English learners. According to Jennifer (2010:43), reading is thinking and understanding and getting at the meaning behind a text. It means that reading is process through which the readers get a message from a written information. According Nuriati (2015:1), reading is one of the ways to communicate in written forms. It means that through reading, someone will get information or message needed. One should comprehend or understand the ideas when they read.

According to Linse and Nunan (2005:69), reading is a set of skills that involves making sense and deriving meaning from printed word. It means that reading is a process of understand the meaning from the text. In reading the text, the reader should comprehend with their text because it can make the reader easier to get main ideas from the text and their reading activity will be success. Further, Harris and Graham (2015:104) pointed out that reading is an activity that has a purpose. It means that reading is a process to get understanding from a text. Scanlon (2010:10) said that the reader can understand information by interpreting source information from the text. Then, reading has purpose to comprehend of the text. To understand text, the reader needs to be able to read the words, retrieve the words' meanings, put the words together to form 
meaningful ideas, and assemble a larger model of what the text is about.

Reading, which is one of the four language skills, can be classified into two types: initial reading and reading comprehension (Cahyono, 2006:37). It means that reading for meaning is essentially an attempt to comprehend texts. It involves a number of metacognitive activities of comprehension monitoring. Learning to read is a process that involves a number of different skills and experiences. It depends on learning to decode individual words and to comprehend the meaning of a text. Reading to learn refers to reading for remembering or studying. It involves all the activities of reading for meaning. Hamra (2010:28) states that the reading material is not only comprehensible but also memorable.

Referring to those explanations, the researcher assumes that reading is an act done by a person to get the meaning of a text. By reading, the reader will know what they read and challenge to response the ideas of the author. The purpose of reading passage commonly is to find information from reading passage and to enhance knowledge of the language being read.

There are many kinds of text in English to read by the students. Every text has the differences in definition, social function, language features, and generic structure. One of the texts learnt in school by the students is personal recount text.

Recount is a kind of text which retells the action happened in the past. According to Cahyono (2011:14), recount text is retelling the experiences in the past. A recount text presents the past experience in the series of events in detail. It means that recount text is the recount text is a type of text that retells an event in the past. In line with Cahyono, 2011), Barwick (2005:4) states that recount text describes an event has occurred in the past. It means that recount is a kind of text that retells about events or experiences in the past. According to Knapp and Watkins (2005:223), recount is the simplest text type in the genre. It means that recount is the easy text for a reader appropriate with genre.

According to Keir (2009), there are three types of recount text. There are (1) personal recount which is a story that tells about activities whereas the writer or speaker involves or do by her or himself. This type uses first pronoun (I, we), (2) factual recount which records the details of a particular incident. A factual recount is concerned with recalling accurately. This type uses the third person pronouns (he, she, it, and they). Some example include: accident report and historical recount, and (3) imaginative recount which gives details of what might have happened in the past. It means that imaginative recount describes an imaginary role and gives details of imaginary events. Based that explanation, the focus of the research is personal recount. It is because personal recount text has been taught to the students by the teacher.

Concerning reading, the most important of reading is comprehension. Tankersley (2003:90) states comprehension is the center of reading. It means that comprehension is the power of reading. It is also influenced by the experience of the reader. Therefore reading is also interaction activity between the text and the reader. Further, Willis (2008:138) states that comprehension is defined as intentional thinking during which meaning is constructed through interactions between and reader. It means that comprehension is understood while reading text. The interaction between texts with the reader is in the process of building understanding of the text. According 
to Brown (1998:306), reading comprehension is primarily a matter of developing appropriate, efficient comprehension strategies. It means comprehension is ability to understand and getting information something. Further, there are some aspects in reading comprehension. They are (1) main idea, (2) expression/idiom/phrase in context, (3) inference (implied detail), (4) grammatical features (reference), (5) detail (scanning for a specifically stated detail), (6) excluding fact not written, (7) supporting idea, and (8) vocabulary in context.

Teaching reading is useful for other purposes. Any exposure to English (provided students understand it more or less) is a good thing for English students (Harmer, 1998:68). It means that teaching reading can make the students understand the text. Teaching reading activity is important for the students. They can understand for what they read and how to read. During teaching reading process, we must pay attention about the principle of teaching reading (Harmer, 1998:68). Teaching reading can provide students with many opportunities to study language, such as vocabulary, grammar, punctuation, and the way we construct sentences, paragraph, and text. Teacher has some principle in teaching reading. The principle can be standard to limit teachers when they teach reading. The principles of teaching reading are stated that reading is not passive skill, students need to be engaged with what they are reading, students should to be encouraged to respond to the content of a reading text, not just to the language, prediction is major factor in reading, match the task to the topic, and good teacher exploit reading texts to the full (Harmer, 1998:101).

Reading comprehension is essential both in Indonesian language and English language. Students may not find any difficulty to comprehend text as reading material in Indonesian language, but what happened to the students when they read text in English language. Many students become frustrated when they found difficulties in reading comprehension of English text because the students do not like learn English language. The students were bored with the technique used by teacher so it made the students lack in reading comprehension. This occurrence also happened to the students at SMA Negeri 2 Tumijajar. Based on preliminary research, the researcher found some students have low score in reading and also most of the students' reading score was under criteria of Brown, which was he stated the reading score of the students was poor when the students get score under 77 .

Besides the students' low reading score, there were some problem faced both teacher and students in the teaching and learning reading process. In teaching reading the teacher used no certain technique, asking students to read without any following activities. Sometimes the teacher asked students to make a pair in learning process. The teacher asked the students about what they read in the paper. The teacher seldom taught reading by fun or interesting ways. In fact, the situation of teaching learning process should be interesting to give the students a relaxed atmosphere in reading comprehension.

There are many kinds of reading technique that can be applied by teacher one of the technique is Buzz Group. According to Nuriati (2015:2), Buzz Group is a technique is a team of four to six students that are formed quickly and extemporaneously to respond to course-related questions in order to get ideas that are generated with a feedback and discussed by whole group. It means that Buzz Group can respond to more questions. 
Therefore by dividing to whole class into small groups, more students have the opportunity to express their thoughts. Further, Barkley (2001:112) states that Buzz Group are teams of four to six students that are formed quickly and extemporaneously to respond to course-related questions. Each group can respond to one or more questions; all groups can discuss the same or different questions. It means that each group can respond to one or more questions; all groups can discuss the same or different questions. Discussion is informal, and students do not need to arrive to consensus, but simply exchange idea.

According to Brewer (1997:72), Buzz Groups encourages more efficient discussion. It means that Buzz Group dividing to whole class into small groups; more students have the opportunity to express their thoughts. Buzz Group set the groundwork to get discussion started. Small group are useful in many instructors prefer to do almost all acquisition activities first in small groups (especially problem-solving and information gathering activities) before doing them with the class as a whole. Furthermore, Svinicki (2006:47) states that one of the popular techniques for achieving students participation in groups is the buzz session. This means the groups can be asked to come up with one hypothesis that they see as relevant, with one application of a principle, with an example of a concept, or with a solution to a problem.

The Buzz Group technique is very effective to be implemented in reading activity because the teacher can divide a large group into smaller groups. It means all students can deliver their own opinion to their friends without being ashamed. This technique is beneficial because it gives all students the freedom to express themselves equally, so every student gets a chance to contribute to the discussion to solving the problem in question. By using Buzz Groups technique, students can learn in the group discussion so that they are easier to express themselves and share their understanding of written text in reading classroom. The Buzz Group technique really provides opportunities for the students to understand the lesson material more by asking each other group member without being ashamed and afraid, since the students are usually afraid to ask the difficulties to the teacher.

Based on those explanations, Buzz Group are teams to four until six students and can help students to trigger their thinking towards the given topic from the teacher. They are given limited time to think and give their argument related to a topic which can make them having fast response. So that, no one in the class thinks slowly and they can also enhance their courage to give the argument in front of the audience.

Concerning the teaching procedure of Buzz Group, Krashen and Terrel (1983:126) mentioned that the procedure of Buzz Group are (1) to form groups; announce the discussion prompts and time limit, (2) to ask group members to exchange ideas in response to the prompts, (3) to check periodically to see whether groups are still actively engaged and focused on the assigned topic. If off topic, shorten the time limit. If on topic and the time has ended, consider extending the limit for a few minutes, and (4) to ask the students to return to whole-class discussion and restate the prompt to begin. That procedure has been arranged into Lesson Plan.

Buzz Group is effective to be implemented in teaching learning reading comprehension. It has been applied by Sari (2015) at SMAN 6 Kediri, on her research entitled "The Effect of Buzz Group Technique 
to the Students' Reading Comprehension at Eleventh Grade of SMAN 6 Kediri Academic Year 2015/2016" which showed that in teaching reading this technique makes the students interested in reading the given text. Another research by Aji (2011) at SMA Negeri 1 Karanganyar, on her research entitled "Using Buzz Group Technique to Improve Students' Reading Comprehension (A Classroom Action Research at the First Grade of SMA Negeri 1 Karanganyar in the Academic Year of 2011/2012)", showed that the students were more active and braver in learning process of reading. It means that using Buzz Group also gives positive effect towards students' reading comprehension.

There were some differences between previous research and this research. The previous research had been done at SMAN 6 Kediri and SMA Negeri 1 Karanganyar meanwhile this research has been done at SMA Negeri 2 Tumijajar. The previous research focused on effect of Buzz Group and improving students' reading, not specific to certain text types, meanwhile this research implemented Buzz Group to teach personal recount text with theme holiday and experience.

Based on those explanations, the researcher tried to investigate the use of Buzz Group as an alternative technique that can be used for teaching English especially for teaching reading comprehension on personal recount text. Finally, the researcher's objective was to find out whether or not there was a significant influence of using Buzz Group towards students' reading comprehension on personal recount text at the eleventh grade of SMA Negeri 2 Tumijajar in the academic year 2018/2019."

\section{METHOD}

\section{Research Design}

This research was quantitative based on the experimental research. An experimental design is the general plan for carrying out a study with an active independent variable. According to Ari (2002:301), the design is important because it determines the study internal validity, which is the ability to reach valid conclusion about the effect of the experimental treatment on the dependent variable.

This research used quasi experimental research design. Quasi experimental design is a research design that includes assignment, but not random assignment of participants to group. Creswell (2012:309) states this is because the experimenter cannot artificially create groups for the experiment. It means that in quasi experimental research design, it was only possible to take intake classes because it can interfere teaching and learning process in that school.

In this research, the researcher selected two classes, one is control class and the other is the experimental class. The researcher used pre-test and post-test group design.

Table 1. Pre and Post-test Design

\begin{tabular}{lccc}
\hline Select Control & Pre-test & No treatment & Post-test \\
Class & & & \\
Select & Pre-test & Treatment & Post-test \\
Experimental & & & \\
Class & & & \\
\hline
\end{tabular}

Based on Table 1, the researcher selected two classes randomly, one class as a control class and one class as an experimental class. Then, the students were given pre-test to know their reading comprehension in personal recount text before treatment. After that, the researcher applied a treatment, Buzz Group technique, in experimental class. After treatment, the students were given a post-test to know whether there was any influence 
students' reading comprehension on personal recount text.

\section{Population, Sample and Sampling Technique}

According to Creswell (2012), a population is a group of individuals who have the same characteristics; the target population is a group of individuals or a group organization with the same common defining characteristics. The population of this research was all the students at the eleventh grade of SMA Negeri 2 Tumijajar 2017/2018 which consisted of 171 that were divided into five classes. Based on those statements, all the classes were the population in this research. In this research, the researcher took two classes by using clustering sampling as the sample of the research, one class as the experimental class, and one class as control class. Experimental class was XI IPA 2 and the control class were XI IPS 2.

\section{Research Instrument}

The instrument was a test of pre-test and posttest after validity consisted of 20 question of reading comprehension on personal recount text. In data collecting technique, the researcher used the following technique:

Pre-test

Pre-test was to know the result of the students before treatment in the class. The researcher got pre-test result in form multiple choices for control and experimental class. The students answered the questions on the answer sheets. Then the researcher did the scoring based on their answers on the test. In pre-test the students were asked to answer reading comprehension test in form of multiple choice questions about personal recount text based on the provided topics that consisted of 20 items with five alternative options and 60 minutes for time allocation.

\section{Post-test}

Post-test the students were asked to answer reading comprehension test in form of multiple choice questions about personal recount text based on the provided topics that consisted of 20 items with five alternative options and 60 minutes for time allocation.

\section{FINDINGS AND DISCUSSION}

\section{Findings}

This research was aimed at knowing whether there was significant influence of using Buzz Group towards students' reading comprehension on personal recount text at the eleventh grade of SMA Negeri 2 Tumijajar in the academic year 2018/2019. The total number of the sample was 66 students, two classes were chosen as control class and experimental class.

The researcher got the data in the form of score. The score was derived from pre-test and post-test. The pre-test was held on November $21^{\text {st }}$ and post-test on November $30^{\text {th }} 2018$. In pre-test, the researcher gave the task for the students before treatment and in the post-test; the researcher gave the task for students to answer the questions after treatment.

After doing the research, the researcher got the result of the pre-test and post-test. The test was conducted in two classes, the first was experimental class and the second was control class.

\section{Result of Pre-test in Experimental Class}


The researcher conducted pre-test in order to know students' ability before the treatment. The pre-test was administrated on November $21^{\text {st }}, 2018$. The scores of students' personal recount text tested in pre-test in the experimental class could be seen in Figure1.

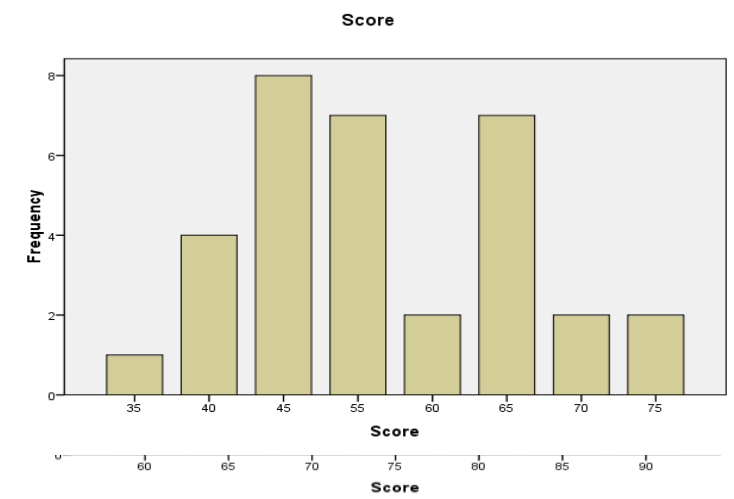

Figure 1. the Result of Pre-Test in Experimental Class

Based on Figure 1, it could be seen that from 33 students, only one students got score 35 , there were four students got score 40, there were eight students got 45 , there were seven students got score 55, there were two students got score 60, there were seven students got score 65, there were two students got score 70, and there were two students got score 75 . For the statistics of result of pre-test in experimental class (XI IPA 2) can be seen on Table 2.

Table 2. Statistics of the Pre-test in Experimental

\begin{tabular}{ll}
\multicolumn{2}{c}{ Class } \\
\hline $\mathrm{N}$ & 33 \\
Mean & 54.70 \\
Median & 55 \\
Mode & 45 \\
Std Deviation & 11.31 \\
Variance & 128.03 \\
Minimum & 35 \\
Maximum & 75 \\
\hline
\end{tabular}

Based on Table 2, it could be seen that $\mathrm{N}$ of pre-test in experimental class was 33 students, mean of was 54.70 , median was 55 , mode was 45 , standard deviation was 11.31 , variance was 128.03 , minimum was 35 , maximum was
75. It showed students' reading ability before they got the treatments.

\section{Result of Pre-test in Control Class}

The researcher conducted pre-test in order to know students' ability before the treatment. The pre-test administrated on November $21^{\text {st }}$, 2018. The scores of students' reading tested in

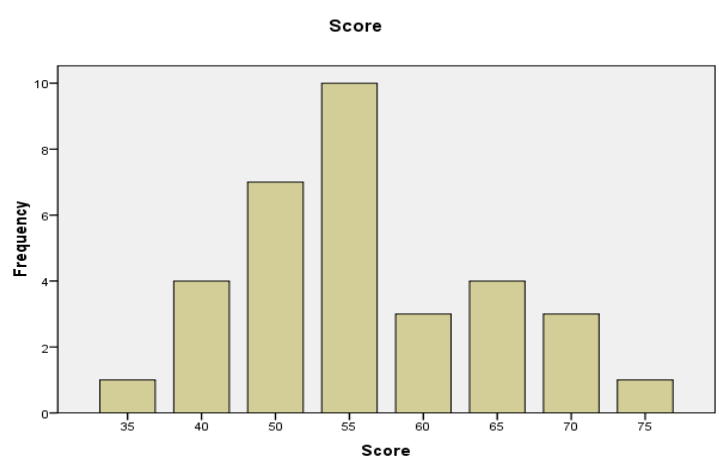

pre-test in the control class could be seen in Figure 2.

Figure 2. the Result of Pre-Test in Control Class Based on Figure 2, it could be seen that from 33 students, only one student got score 35, there were four students got score 40 , there were seven students got 50 , there were ten students got score 55, there were three students got score 60, there were three students got score 70, only one students got 75. For the statistics of pre-test in control class (XI IPS 2) can be seen on Table 3.

Table 3. Statistics of the Pre-test in Control Class

\begin{tabular}{ll}
$\mathrm{N}$ & 33 \\
Mean & 55.15 \\
Median & 55 \\
Mode & 55 \\
Std Deviation & 9.72 \\
Variance & 94.50 \\
Minimum & 35 \\
Maximum & 75 \\
\hline
\end{tabular}

Based on Table 3, it could be seen that $\mathrm{N}$ of pre-test in control class was 33 students, mean of was 55.15, median was 55, mode was 55, 
standard deviation was 9.72, variance was 94.50, minimum was 35, maximum was 75 .

\section{Result of Post-test in Experimental Class}

The researcher also gave post-test in

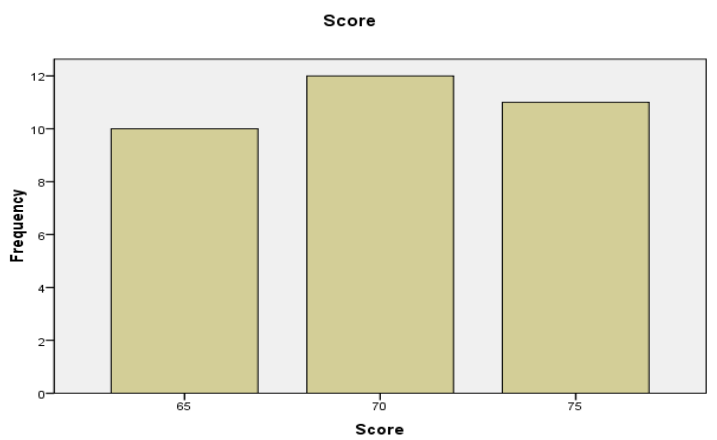

experimental class to know students' personal recount text after the treatment. It was administrated on November $30^{\text {th }}, 2018$. The scores of post-test in experimental class are presented in Figure 3.

Figure 3. the Result of Post-Test in Experimental Class

Based on Figure 3, it could be seen that from 33 students, only one students got score 60, only one students got score 65 , there were seven students got 70 , there were ten students got score 75 , there were five students got score 80 , there were eight students got score 85, only one students got score 90. For the statistics of post-test in experimental class (XI IPA 2) can be seen on Table 4.

Table 4. Statistics of the Post-test in Experimental Class

\begin{tabular}{ll}
\hline $\mathrm{N}$ & 33 \\
Mean & 76.82 \\
Median & 75 \\
Mode & 75 \\
Std Deviation & 6.93 \\
Variance & 48.15 \\
Minimum & 60 \\
Maximum & 90 \\
\hline
\end{tabular}

Based on Table 4, it could be seen that $\mathrm{N}$ of post-test in experimental class was 33 students, mean of was 76.82 , median was 75 , mode was 75 , standard deviation was 6.93 , variance was 48.15 , minimum was 60 , maximum was 90 . It showed students' reading ability after they got the treatments.

\section{Result of Post-test in Control Class}

The researcher also gave post-test in control class to know students' personal recount text after the treatment. It was administrated on November $30^{\text {th }}, 2018$. The scores of post-test in control class are presented in Figure 4.

Figure 4. Graphs of the Result of Post-Test in Control Class

Based on Figure 4, it could be seen that from 33 students, there were ten students got score 65 , there were twelve students got score 70, there were eleven students got 75 . For the statistics of post-test in control class (XI IPS 2) can be seen on Table 5 .

Table 5. Statistics of the Post-test in

\begin{tabular}{lc} 
& Control Class \\
\hline $\mathrm{N}$ & 33 \\
Mean & 70.15 \\
Median & 70 \\
Mode & 70 \\
Std Deviation & 4.04 \\
Variance & 16.38 \\
Minimum & 65 \\
Maximum & 75 \\
\hline
\end{tabular}

Based on Table 5, it could be seen that $\mathrm{N}$ of post-test in experimental class was 33 students, mean of was 70.15 , median was 70 , mode was 70 , standard deviation was 4.04 , variance was 16.38 , minimum was 65 , maximum was 75 .

\section{The Result of Data Analysis Fulfillment of the Assumptions}

After collecting the data, the researcher analyzed the data by using independent sample t-test. There were two assumptions that were done, before the researcher analyzed the data by using t-test.

\section{The Result of Normality Test}


The normality test was used to measure weather the data in the experimental class and control classes are normally distributed or not.

The hypothesis formulas were:

$\mathrm{H}_{\mathrm{o}}=$ the data have normal distribution .

$\mathrm{H}_{\mathrm{a}}=$ the data do not have normal distribution.

The criteria of the test were:

$\mathrm{H}_{\mathrm{o}}$ is accepted if Sig. $\left(\mathrm{p}_{\text {value }}\right) \geq \alpha=0.05$

$\mathrm{H}_{\mathrm{a}}$ is accepted if Sig. $\left(\mathrm{p}_{\text {value }}\right)<\alpha=0.05$

Table 6. The Result of Normality Test

\begin{tabular}{lccc}
\hline & \multicolumn{3}{c}{ Shapiro-Wilk } \\
& Statistic & df & Sig. \\
\cline { 2 - 4 } $\begin{array}{l}\text { Experimental } \\
\text { Class }\end{array}$ & .956 & 33 & .195 \\
Control Class & .939 & 33 & .064 \\
\hline
\end{tabular}

Based on the result of normality test, it can be seen that Sig. ( $\mathrm{p}_{\text {value }}$ ) for experimental class was 0.195 and Sig. ( $p_{\text {value }}$ ) for control class was 0.064 and $\alpha=0.05$. It means that Sig. $\left(\mathrm{p}_{\text {value }}\right)>\alpha$ and Ho is accepted. The conclusion is that data in experimental and control class had normal distribution.

\section{The Result of Homogeneity Test}

The researcher tested homogeneity test after he got the score of students' reading comprehension in experimental class and control class (pre-test and post-test of students' reading comprehension by using SPSS).

The hypothesis were:

$\mathrm{H}_{\mathrm{o}}=$ the variances of the data are homogenous

$\mathrm{H}_{\mathrm{a}}=$ the variances of the data are not homogenous

The criteria of the test were:

$\mathrm{H}_{\mathrm{o}}$ is accepted if Sig. $\geq \alpha=0.05$

$\mathrm{H}_{\mathrm{a}}$ is accepted if Sig. $<\alpha=0.05$
Table 7. The Result of Homogeneity Test

\begin{tabular}{rrrr}
\hline Levene Statistic & df1 & df2 & Sig. \\
\hline .002 & 1 & 64 & .964 \\
\hline
\end{tabular}

Based on the result in the test of homogeneity of variance in Table 7, it can be seen that Sig. ( $p_{\text {value }}$ ) was $0.964>\alpha=0.05$. It means that Ho was accepted because Sig. $\left(\mathrm{p}_{\text {value }}\right)>\alpha$ was 0.05 . It means that the variance of the data were homogeneous.

\section{The Result of Hypothetical Test}

After the researcher knew that the data were normal and homogeneous, the data were analyzed by using independent sample t-test in order to knew the significance of the treatment effect. Therefore, the researcher used SPSS to calculate independent sample ttest.

The hypothesis formulas were:

$\mathrm{Ha}$ : There is significant influence of using Buzz Group towards students' reading comprehension on personal recount text at the eleventh grade of SMA Negeri 2 Tumijajar in the academic year 2018/2019.

Ho : There is no significant influence of using Buzz Group towards students' reading comprehension on personal recount text at the eleventh grade of SMA Negeri 2 Tumijajar in the academic year 2018/2019.

The criteria of the test were:

$\mathrm{H}_{\mathrm{a}}$ is accepted if Sig. $\left(\mathrm{p}_{\text {value }}\right) \leq \alpha=0.05$

$\mathrm{H}_{\mathrm{o}}$ is accepted if Sig. $\left(\mathrm{p}_{\text {value }}\right)>\alpha=0.05$

Table 8. the Result of Hypothetical Test

\begin{tabular}{ccc}
\hline $\mathrm{T}$ & $\mathrm{Df}$ & Sig. (2-tailed) \\
\hline 3.267 & 63 & .002 \\
\hline
\end{tabular}


Based on the result in the independent sample t-test in Table 8 , the value of significant generated Sig. ( $\left.p_{\text {value }}\right)$ or Sig. (2-tailed) was 0.02 and $\alpha$ was 0.05 . It means that $\mathrm{Ho}$ is rejected and $\mathrm{Ha}$ is accepted. Based on the computation, it can be concluded that there was any significant influence of using Buzz Group towards students' reading comprehension on personal recount text at the eleventh grade of SMA Negeri 2 Tumijajar.

\section{Discussion}

The research had been conducted since November $20^{\text {th }}, 2018$. The objective of this research was to find out whether the use of Buzz Group technique can increase students reading comprehension on personal recount text at the eleventh grade of SMA Negeri 2 Tumijajar in the academic year 2018/2019. Based on the research method, this research was divided into same step. In the first step, the researcher conducted try-out in try-out class. The researcher prepared 40 items of multiple choice questions for pre-test and post-test. After the researcher gave try-out, the researcher calculated test items to know validity of the test. The result showed that 20 items of pre-test and post-test instrument were valid.

At the beginning of the research, the pre-test was administrated to know students' achievement in reading personal recount text before they were given treatments by the researcher. The result showed that the mean score pre-test in experimental class was 54.70 and the mean score of pre-test in control class was 55.15. It can be concluded that there is significant influence by using Buzz Group towards students' score in experimental and students got score post-test higher than pretest in experimental class.
Afterward, the students were taught by using Buzz Group in the experimental class and think pair share in control class. The material was three topics of personal recount text for three meetings. Before doing Buzz Group the researcher explained what the Buzz Group and how we the procedure of Buzz Group was. In the beginning of the treatment the researcher asked the students about personal recount text and explained it to students.

At the end of the research, post-test was given to measure the improvement of students' personal recount text reading comprehension in both classes after the treatments done. According to the result of data by using SPSS, the result showed that the mean score of post-test between experimental class and control class were slightly different. The mean score of post-test in experimental class was 76.82 and the mean of post-test in control class was 70.15 .

Based on the analysis of the data and the hypothesis testing, the result of t-test was that null hypothesis $\left(\mathrm{H}_{\mathrm{o}}\right)$ was refused and alternative hypothesis $\left(\mathrm{H}_{\mathrm{a}}\right)$ was accepted. It meant that the treatments had influence of using Buzz Group towards students' reading comprehension on personal recount text, so alternative hypothesis was accepted. In this case, Buzz Group also gave students chance to work with a group discussing

In conclusion, Buzz Group was more helpful to be used for the students to help them built their reading comprehension. It was because Buzz Group not only asked students to work individually but also in group, so the students would be more confident when they read and comprehend the text. The findings of this research were relevant with some previous studies. The previous research was conducted by Sari and Aji, on her research entitled "The Effect of Buzz Group Technique 
to the Students' Reading Comprehension at Eleventh Grade of SMAN 6 Kediri Academic Year 2015/2016", and by Aji "Using Buzz Group Technique to Improve Students' Reading Comprehension (A Classroom Action Research at the First Grade of SMA Negeri 1 Karanganyar in the Academic Year of 2011/2012)", Finally, there is significant influence of using Buzz Group towards students' reading comprehension on personal recount text at the eleventh grade of SMA Negeri 2 Tumijajar in the academic year 2018/2019.

\section{CONCLUSION AND SUGGESTION}

\section{Conclusion}

At the end of the research, the post-test was given to measure the influence of Buzz Group towards students' reading comprehension on personal recount text in both classes after treatments done. The mean score of post-test in experimental class was 76.82 and the mean score of post-test in control class was 70.15. It showed that the students' post-test score in experimental class was higher than students' post-test score in control class. The result can be seen from Sig. $=0.002$. It was lower than $\alpha$ $=0.05$ and this meant that Ho was rejected and Ha was accepted. Based on the result of data analysis, the researcher concluded that there was significant influence of using Buzz Group towards students' reading comprehension on personal recount text at the eleventh grade of SMA Negeri 2 Tumijajar in the academic year 2018/2019.

\section{Suggestion}

Based on the research result that has been discussed in conclusion, the researcher had some suggestions.
In this research, the researcher found out that Buzz Group can be used to develop and motivate the students' reading comprehension. Due the finding, English teacher can help students increase their reading comprehension by using Buzz Group. The English teachers should provide interesting activities and materials, in order to prevent the students from being bored and encourage the students' attention in learning English, especially in reading. Buzz Group is a good technique to help students in increasing reading comprehension.

\section{Suggestions for the students}

The students should be more active in learning reading text and the students have to read more reading text to have more knowledge. The students can apply the Buzz Group technique in their reading activities to increase their reading ability. The students need to be brave to exchange their ideas with their classmates.

\section{Suggestion for the further research}

In this research the researcher focused on the influence of Buzz Group towards students' reading comprehension on personal recount text. Buzz Group technique is effective to be implemented in reading activity because the research can divide a large group into smaller group. The students can deliver their idea or opinion and get chance to contribute to the discussion to solving their problem in questions. It is suggested for the next researcher to investigate the influence of other technique towards other English skills such as listening, speaking or writing ability. 


\section{REFERENCES}

Aji, Rista Karisma Putri. Using Buzz Group Technique to Improve Students' Reading Comprehension (A Classroom Action Research at the First Grade of SMA Negeri 1 Karanganyar in the Academic Year of 2011/2012).

Anderson, Mark and Katty Anderson. Text Types in English 2. (South Yarra: Mac. Millan, 2003).

Arikunto, Suharsimi. Dasar-dasar Evaluasi Pendidikan. (Jakarta: Bina Aksara, 1989).

Ary, Donald. et.al. Introduction to Research in Education, ( ${ }^{\text {th }}$ Edition). (Belmont: Wadsworth Cengage Learning, 2002).

Barkley, Elizabeth F. et.al. Collaborative Learning Techniques: a handbook for college faculty. (San Fransisco: JosseyBass, 2001).

Barwick, John. et.al. Targeting Text: Recount, Procedure, Exposition, (New South Wales: Blake Education, 1999).

Brewer, Ernest W. 13 Proven Ways to Get Your Message Across: The Essential Reference for Teachers, Trainers, Presenters, and Speakers. (California: Corwin Press, 1997).

Brown, H. Douglas. Language Assessment: Principle and Classroom Practice. (New York: Pearson Education, 2004).

Brown, H. Douglas. Principles of Language Learning and Teaching Fourth Edition. (New York: Pearson Longman, 2000).
Cahyono, Bambang and Utami Widiati. The Teaching of EFL Reading in Indonesian Context: The State of The Art. (TEFLIN Journal, 2006). Vol. 17 No. 1.

Cahyono, Bambang Yudi. Teaching English by Using Various Text Type. (Malang: State University of Malang Press, 2011).

Creswell, John W. Educational Research: Planning and Conducting Quantitative and Qualitative Research. (Boston: Pearson, 2012).

Fraenkel, Jack R. and Norman E. Wallen. How to Design Evaluate Research in Education. (New York: McGraw-Hill, 2008).

G. Woolley. Reading Comprehension: Assisting Children with Learning Difficulties. (Springer Science: 2011).

Gerot, Linda and Peter Wignell. Making Sense of Functional Grammar. (New South Wales: Gerd Stabler, 1994).

Hamra, Arifudin and Enny Syatriana. Developing a Model of Teaching Reading Comprehension for EFL Students. (TEFLIN Journal, 2010). Vol. 21, No. 1.

Harmer, Jeremy. How to Teach English (An Introduction to the Practice of English Language Teaching). (England: Longman, 1998).

Harris, Karen R. and Steve Graham. Teaching Reading Comprehension to Students Learning Difficulties, (New York: Guildford Press, 2007). 
Hartono, Rudi. Genres of Text. (Semarang: Unes, 2005).

Hedgock, John S. Hedgcock and Dana R. Ferris. Teaching Readers of English: Students, Texts, and Contexts. (New York: Routledge, 2009).

Hyland, Ken. Teaching and Researching Writing ( $\left.2^{\text {nd }} E d\right)$. (Britain: Pearson Education, 2002).

Johnson, Keit. An Introduction to Foreign Language Learning And Teaching. (New York: Routledge, 2013)

Kagan, Spencer. Cooperative Learning the Structural Approach. (Annual Summer Institute: Kagan Publishing, 1990).

Keir, June. 2009. Informative Texts. Australia: Ready-Ed Publication

Knapp, Peter Knapp and Megan Watkins. Genre, Text, and Grammar (Technologies for Teaching and Assessing Writing). (Sidney: University of New South Wales Press Ltd, 2005).

Krashen, Stephen D. and Tracy D. Terrel. The Natural Approach: Language Acquisition in the Classroom, (London: Prentice Hall Europe, 1983).

Lines, Caroline and David Nunan. Practical English Language Teaching: PELT Young Learners. (New York: McGraw-Hill Companies, 2005).

Margono. Metodologi Penelitian Pendidikan. (Jakarta: Rineka Cipta, 2007).
McCune, Sandra Luna. et.al. Cliffs Notes Praxis II. (Canada: Wilcy Publishing, 2009).

Muijs, Daniel. Doing Quantitative Research in Education. (California: Sage Publication, 2004).

Nuriati. et.al. Improving Students' Reading Comprehension by Using Buzz Group Technique. (E-Journal of English Language Teaching Society (ELTS), 2015). Vol. 3, No. 2.

Sari, Yuni Indah Novita. The Effect of Buzz Group Technique to the Students' Reading Comprehension At Eleventh Grade Of SMAN 6 Kediri Academic Year 2015/2016.

Scanlon, Donna M. et.al. Early Intervention for Reading Difficulties: The Interactive Strategies Approach. (New York: The Guilford Press, 2010).

Serravalo, Jennifer. Teaching Reading in Small Group. (Portsmouth: Heinemann, 2010).

Siahaan, Sanggam. Generic Text Structure. (Yogyakarta: PT Graha Ilmu, 2007).

Svinicki, Marilla and Wilbert J. McKeachie. Teaching Tips, Strategy, Research and Theory for College and University Teacher $\left(13^{\text {th }} E d\right)$. (USA: Wadsworth, 2006).

Tankersley, Karen. Threads of Reading: Strategy for Literacy Development. (United State of America: Library of Congress Cataloging in Publication Data, 2003). 
Tantya, Lia Aris and Syaifudin Latif Darmawan. The Influence of Using Think Pair Share and Pairs Check Technique Toward Students' Writing Ability in Recount Text At The Students Of SMP N 2 Pekalongan Academic Year 2013/2014. (Premise Journal ISSN 2089-3345, 2014). Vol. 3, No. 2.

Tint, San San and Ei Ei Nyunt. Collaborative Learning with Think-Pair-Share Technique. (Computer Applications: An International Journal (CAIJ), 2015). Vol.2, No.1.

Walker, Donna E. Strategy for Teaching Differently. (California: Corwin Press Inc, 1998).

Willis, Judy. Teaching the Brain to Read: Strategies for Improving Fluency, Vocabulary, and Comprehension. (Virginia: ASDC Publications, 2008). 